\title{
A Comparison Study of Stock Market Returns Given by the Newsweek 500 Green Companies and Broad Market Indices in US
}

\author{
Dr.Vimala Sanjeevkumar \\ Associate Professor, College of Business, University of Utara, Sintok, Kedah, Malaysia \\ Email: sanjeevcv2000@gmail.com,Virmala@uum.edu.my
}

Accepted: November 2, 2011 Published: December 06, 2011

Doi:10.5296/ijld.v1i1.1145ＵRL: http://dx.doi.org/10.5296/ijld.v1i1.1145

\begin{abstract}
"Going green" is no longer a fringe topic. The green revolution has already started, and is going green from the bottom up and the top down. Going green is about sustainability. Corporations exhaust resources, pollute the environment, generate large amount of waste and engage themselves in tons of unsustainable practices. These practices become an expense to the nation. Businesses are finding ways to protect the environment, particularly though developing standards and green certification programs. Some corporations are responding to the requirements of consumers to buy products with less impact on the environment (i.e) in their creation, packaging, marketing, use, and disposal. Furthermore with scientific and global consensus that human activities and carbon emissions contribute significantly to climate change, corporations no longer have the choice to ignore being environmentally sensitive. Green practices can be rewarding in the long run as it ensures that natural resources can be sustained as long as possible. Many investors are also prepared to put their money into green businesses because they see that sustainable practices are actually more profitable in the long term. Recent developments in technology have made it easier to protect the environment, and many businesses have learned that a sustainable supply chain is a valuable asset.

Furthermore green companies are now gaining greater consumer acceptance as they are portrayed as the more responsible business. The Top 500 companies ranked by the 2009 Newsweek Green Rankings shows a noteworthy green attitude which consumers adore, therefore the publicity which these companies get will in turn translate into more customers and improve their profits ultimately. This study focuses on the green ranked companies thereby analyzing whether the returns of these companies meet the broad market return.
\end{abstract}


Keywords: Green revolution, Sustainability, Global consensus, Green practices, Green ranking

\section{Introduction:}

With the growth in corporate responsibility efforts over the last two decades has come an increasing number of questions about whether and how investors value these initiatives. The recent financial crisis has brought improved attention to the investor perspective and potentially an opportunity to increase the consideration of companies' social and environmental performance in investment analyses. Many companies have also begun asking how they can evolve their communications on Environmental, Social, and Governance factors to these mainstream investors. In the past few years, topics in global warming and climate change have moved high on the international agenda. There is new impetus for U.S. companies to make energy-efficient, or green, choices. To improve the quality of living, the perception of "green investing" is costly has changed. People are calling for corporations to make changes and some are even willing to pay more for corporations to produce greener products.

\section{Green Building}

Companies are taking green building and the subsequent savings in energy, natural resources, and money seriously. The savings to companies can be large.

\section{Green Energy}

Technology advances are also leading U.S. corporations to increase the amount of alternative energy they use. And government incentives are making alternative energy, such as solar and wind power, economically feasible. Companies are also finding less expensive ways to incorporate green energy

\section{Green Operations}

Businesses are serious about reducing the amount of energy they use to run their operations. The focus for most companies today is developing a "sustainable" supply chain — one that is robust enough to support itself and actually improve the environment. By moving toward a sustainable green supply chain, companies will uncover new opportunities to reduce costs.

\section{The Rise Of Corporate Stakeholders}

In recent years, U.S. corporations have reduced environmental emissions and in response to pressures from governments, investors, environmental groups, customers, and employees are developing pollution prevention strategies. Increasingly, corporate leaders see that managing environmental issues effectively can be a significant source of competitive advantage and sustainable growth. The bottom line is that most American corporations now 
believe they can create a significant source of competitive advantage and sustainable growth by having effective environmental management. Being "green," is seen as good business.

\section{The Power Of Stakeholders}

The key to modern corporate motivation is a company's concern for building rapport with its stakeholders. Government policy makers, customers, environmental groups, investors, and employees constitute major stakeholders and exert pressures on shaping a firm's environmental strategy. To reach out to these groups, companies use public disclosure and consultations about their activities and their impacts on the environment.

Government: Government regulation is a major driver of environmental policy. Exponential growth in environmental laws forces companies to anticipate and make investments to meet new requirements even before the laws are passed.

Customers: Customers, both as voters and as buyers of products and services, have a significant impact on environmental policy. According to a USA Today/Gallup Poll conducted in March 2007, more than 8 in 10 Americans consider that a company's environmental record should be an important factor in deciding whether to buy its products. Environmental Groups:. Environmental organizations are using their power to develop tough regulations and also to extend the areas regulated. In addition, these organizations can take other actions that encourage companies to be green.

Investors: Poor environmental performance can increase costs, because companies that produce large quantities of waste tend to have a higher number of spills and hazardous waste sites, and serious compliance problems. Investors can hold corporations accountable for environmental performance by speaking directly with corporate management, filing shareholder resolutions, and voting against the management. If they are still not satisfied, they can withdraw their investment by selling their stocks. In recent years, shareholders have been successful in convincing major banks to consider the environmental risks of projects they consider financing, persuading computer manufacturers to increase the number of computers they recycle, and encouraging public utilities to invest in renewable energy.

Employees: Employees bear most of the impact of poor environmental practices. Attracting employees to work in unsafe surroundings is expensive, and workers and their unions often pressure companies to reduce pollution. If employees are ignored, they often respond by changing jobs or by mobilizing public support. Costs can also rise because of higher employee turnover. Companies respond by providing employee training on environmental health and safety and on environmental management systems.

\section{Consumers Demand Green}

Consumers seem to be recognizing what their consumption does to the environment. These consumers are smart, and they want the companies with which they do business to be smart as well. That means creating products that help consumers organize their lives, achieve personal and business success, look their best, feel their best and also that help them lower 
their carbon footprint. In today's world it is difficult not to be aware of the impact we are having on our limited resources. And it is that concern that has companies catering to consumers' desires to be less offensive to the environment. Indeed, "green" is the new buzzword making its way into the mainstream via commercials, television shows, company dossiers, and conferences. The environmental initiative has made its way to an industry infamous for depleting forests and gobbling up green spaces.

\section{Corporate Executives On Going Green Steve Ballmer, Microsoft CEO}

Explaining that PCs and other technology still consume far too much electricity, Ballmer said: "The lowering of energy consumption is as important for us as new uses of software and IT for the environment." (2008, CeBit Technology Show in Hannover, Germany)

\section{Steve Jobs, Apple CEO}

It is generally not Apple's policy to trumpet our plans for the future; we tend to talk about the things we have just accomplished. Unfortunately this policy has left our customers, shareholders, employees, and the industry in the dark about Apple's desires and plans to become greener. Our stakeholders deserve and expect more from us, and they're right to do so. They want us to be a leader in this area, just as we are in the other areas of our business. So today we're changing our policy." (Apple Web site) [http://www.apple.com/hotnews/agreenerapple/]

\section{Jeffrey Immelt, GE (General Electric) Chairman and CEO}

"We looked across our company and recognized that a focus on environmental technology could be a big business initiative for the company. The concept we worked on at the time was this notion that green is green. In other words, the time had come that, through technology, we felt like we could create a good business initiative to focus on conservation and greenhouse gas emission reduction and do good business at the same time." (2007, interview with VerdeXchange News) [http://www.verdexchange.org/node/82]

\section{THE GREENEST BIG COMPANIES IN AMERICA}

When David Roberts was growing up near the oilfields of West Texas in the early 1960s, it never got dark and the oilfields were lit $24 / 7$ by the gas flares used to burn off natural gas, a by product of oil drilling. The flares released massive amounts of $\mathrm{CO} 2$, and over time, oil companies halted that harmful practice in the U.S. But gas flares remain the norm in the developing world - and today Roberts oversees a team at Marathon Oil that's trying to end the practice. In 2007, Marathon opened a \$1.5 billion liquid-natural-gas plant in Equatorial Guinea to capture the natural gas that once went up in smoke. The plant is one factor that 
helped Marathon, No. 100 in Newsweek's Green Rankings, cut its CO2 emissions by 40 percent between 2004 and 2008 - and the plant earns a profit.

It's a small example of how the economic case for going green is becoming more compelling. Economists view environmental damage as a classic "externality"—a cost that impacts society but isn't imposed on producers or consumers. But with scientific consensus that carbon emissions threaten our climate, there's growing political will to curb them, particularly with the global powers set to meet in Copenhagen in December. The Obama administration is pushing for a cap-and-trade system that would turn companies' emissions into a bottom-line cost. Smart companies are working to better understand-and cut—-those emissions ahead of new regulations.

The inaugural Newsweek Green Rankings recognizes those efforts. For more than a year, the magazine worked with leading environmental researchers KLD Research \& Analytics, Trucost, and CorporateRegister.com to rank the 500 largest U.S. companies based on their actual environmental performance, policies, and reputation. Ranking companies based on sustainability is a huge challenge. Some industries are far dirtier than others: a typical financial-services company exacts a smaller environmental toll than even the best-run utility or mining company. Also, many corporations are secretive about key environmental data, if they track the numbers at all. Even among companies that do report green data, there's no uniform standard, so their numbers often aren't comparable.

Despite those obstacles, the members worked hard to design a ranking system that makes sense. More than half of companies' overall Green Scores are based on their environmental policies and reputation, industry-neutral metrics that help even the playing field for companies in carbon-intensive businesses. To overcome limited corporate emissions numbers, Newsweek used data from Trucost, which has created a widely acclaimed system for estimating emissions of companies that fail to provide them. "One of the purposes of this is to improve the transparency of corporations... and encourage them to provide an even higher level of disclosure," says Thomas Kuh, KLD's managing director.

Many of the companies that finished in Top 100 are recognized leaders in sustainability. Intel, No. 4 in Newsweek's ranking, recently launched an initiative in which every employee's annual bonus is tied, in part, to how well the company does in meeting sustainability goals. Wal-Mart, No. 59, recently announced plans to create a Sustainability Index that will help consumers better understand which products sold in its stores are greener than others. Rankings inevitably provoke controversy and Newsweek hope is to open a conversation on measuring environmental performance an essential first step toward improving it.

\section{Green Rankings 2009: Methodology}

Newsweek collaborated with three research partners to compile the rankings: KLD Research \& Analytics, which tracks environmental, social and governance data on companies worldwide and served as lead partner; Trucost, which specializes in quantitative environmental performance measurement; and CorporateRegister.com, the world's largest online directory of social responsibility, sustainability and environmental reporting. The 
goal was to assess each company's actual resource use and emissions and its policies and strategies, along with its reputation among its peers. The 500 companies included in the ranking are the largest U.S. companies as measured by revenue, market capitalization and number of employees. The companies are broken out into 15 sectors, based on the FTSE/Dow Jones Industry Classification Benchmark (ICB).

The GREEN SCORE for each company is based on three components: The ENVIRONMENTAL IMPACT SCORE, based on data compiled by Trucost, is a comprehensive and standardized quantitative performance measurement that captures the total cost of all environmental impacts of a corporation's global operations. Over 700 variables are summarized in the EIS. This figure is normalized against a company's annual revenues, so that companies of all sizes and industries can be compared.

The GREEN POLICIES SCORE, derived from data collected by KLD, reflects an analytical assessment of a company's environmental policies and performance. Its scoring model captures best-in-class policies, programs and initiatives, as well as regulatory infractions, lawsuits and community impacts, among other indicators.

The REPUTATION SCORE is based on an opinion survey of corporate social responsibility (CSR) professionals, academics and other environmental experts who subscribe to CorporateRegister.com. CEOs or high-ranking officials in all companies on the Newsweek 500 list were also invited to participate.

KLD, Trucost and CorporateRegister.com scored each company according to their specific methodologies, and then converted the results to Z-scores, a widely accepted statistical technique that measures how well a firm compares to the average score of the collective group. The overall Newsweek Green Score was calculated as the weighted sum of the three component Z-scores: 45 percent for the Environmental Impact Score, 45 percent for the Green Policies Score, which takes into consideration sector differences, so that various industries can be judged against each other and 10 percent for the Reputation Score, which also reflects sector analysis. The rankings also contain a column reporting each company's emissions of greenhouse gases (GHGs) - a reflection of the importance of GHGs as a key component in a corporation's environmental footprint. The GHG data for the rankings comes from Trucost. Newsweek.com contains additional GHG data reported by companies to KLD, Trucost and the Carbon Disclosure Project, which collects GHG data on over 2,500 companies worldwide.

This methodology and weightings were created in consultation with an independent advisory panel. The panel's members include: Daniel Esty, Hillhouse Professor of Environmental Law and Policy at Yale University; Marjorie Kelly, Senior Associate at the Tellus Institute and co-founder of Business Ethics; John Steelman, Climate Centre, National Resources Defense Council; Wood Turner, executive director of Climate Counts; and David Vidal, Global Corporate Citizenship Research Director, the Conference Board. Newsweek's editorial partner on the Green Rankings project is ASAP Media. Founded by journalists and editors Peter Bernstein and Annalyn Swan, ASAP Media specializes in magazine, book and web content development. 


\section{Macrothink Institute ${ }^{\mathrm{T}}$

\section{Environmental Impact Score}

Four of the major elements that contribute to the overall EIS score (and which are broken out into separate columns) are: greenhouse gas emissions (including nine gases in total, with carbon dioxide the most important in many cases), water use (including direct, purchased and cooling), solid waste disposed, and acid rain emissions (sulphur dioxide, nitrogen oxide and ammonia), all normalized by revenue. All data included in the four columns comes from Trucost based on: standardized company reported data, fuel/resource use, and production based company estimates. Additionally, separate columns on toxic waste emissions and emissions normalized against a company's annual revenues are included. Emissions data is derived from the Toxic Release Inventory, a U.S. Environmental Protection Agency database of information on toxic chemical releases and waste management activities.

\section{Green Policies Score}

The main elements incorporated in the GPS score are: climate change policies and performance, pollution policies and performance, product impacts, environmental stewardship and environmental management.

\section{Reputation Score}

The opinion survey, which was done exclusively for Newsweek, went out to 13,000 CorporateRegister.com users, of whom 6,600 are located in the U.S. and 6,400 are based internationally. Of those surveyed, 4,500 were identified as "sector specialists"—-those having a specific working knowledge of environmental issues within their industry - and were only asked to score their sector peers. Additionally, CEOs or high-ranking officials in all companies on the Newsweek 500 list were invited to participate. CEO scores were given a weight of "3," sector specialists a weight of "2," and other participants a weight of "1." Any scores given to a company by its own employees were disregarded.

The survey asked respondents to rate companies as "leaders" or "laggards" in five key "green" areas: green performance, commitment, communications, track record and ambassadors. There were a total of 808 respondents or a six percent response rate, a far higher response than is typical of most public opinion polls reported in the media.

\section{Z-scores}

For presentation purposes, KLD mapped the overall Green Score, the Green Policies Score and the Reputation Survey Z-scores to a 100 point scale, with the Environmental Impact Score mapped to a 100 point scale using Trucost's underlying environmental impact ratio scores. It is important to note that because of the mapping to a 100-point scale, a 45-45-10 weighting applied to each individual component will not result in the overall Green Score. 


\section{Al Macrothink}

\section{Need For The Study}

With the recent drive to try and preserve the environment and reduce harmful emissions companies are increasingly realizing that going green could be a new way for companies to save or even make more green. The trend toward going green is extending beyond the most obvious polluters, and reaching companies ranging from big Wall Street firms to technology mainstays. The average person might believe that the worldwide push to "go green" is coming solely from politicians and concerned citizens. In fact, this is not the case! In recent years, many big-name companies have realized their way towards more sustainable and eco-friendly business practices. Companies ranging from retailing titan Wal-Mart to investment firm Goldman Sachs are jumping on the green bandwagon and pledging to make tangible changes that go beyond the public relations-oriented "green washing" of years past. Most business leaders now recognize that they need to take new measures to reduce their companies' effects on the environment.

Thus this study focuses on analysis whether the market returns of those companies that are ranked as "green companies" by Newsweek meet the broad market returns.

\section{Objective Of The Study}

- To assess whether companies that embrace eco-friendly practices gives a stock market return lesser than the returns given by the broad market.

- To find out the stock market returns for each of the company that is ranked by the Newsweek in a 1 year, 2 year, 3 year, 4 year \& 5 year time frame.

- To find out where the annual stock return of the companies at least meet the broad market return.

- To find out the average returns given by the following clusters for a 1 year, 2 year, 3 year, 4 year \& 5 year time frame

○ Top 50 companies

○ Top 100 companies

o Top 250 companies

o All 500 companies in the list

- To calculate the returns for the indices mentioned below for a 1 year, 2 year, 3 year, 4 year \& 5 year time frame.

○ Dow Jones Industrials (DJI)

○ Dow Jones Composite (DJA)

○ S\&P 500 (GSPC)

o NYSE Composite (NYA)

○ NASDAQ Composite (IXIC)

- Dow Jones Wilshire (DWC)

- Russell 3000 (RUA)

- To find out the average returns given by the following clusters for a 1 year, 2 year, 3 year, 4 year \& 5 year time frame

o 1-100 companies 
○ 101-200 companies

○ 201-300 companies

○ 301-400 companies

o 401-500 companies

- To compare and contrast the average returns of the cluster and the returns of the indices for a 1 year, 2 year, 3 year, 4 year \& 5 year time frame.

\section{Review of Literature}

- Asset Management Working Group (AMWG), the United Nations Environment Programme Finance Initiative and Mercer. (2007) "Demystifying Responsible Investment Performance; A Review of Key Academic and Broker Research on ESG Factors".

"There is already explicit evidence and acknowledgment of the materiality of ESG factors and its influence in driving business strategy. Addressing ESG factors appears to be currently centered on improving risk management, mainly for large caps. The opportunity side is largely viewed through a thematic lens, mainly for small and mid caps, with a primary focus on environmental aspects."

- $\quad$ Larson, Andrea. (2008) "Screening Investments of Stakeholders: Socially Responsible Investing in the United States". Vol., pp. 1-16, Available at SSRN: http://ssrn.com/abstract=909027. Accessed: Nov. 13, 08.

The goal of socially responsible investing (SRI) is to provide capital to the companies that are socially and environmentally responsible and to deny capital to the ones that are not. SRI involves integrating personal values and societal concerns with investment decisions so as to promote greater corporate responsibility. This technical note discusses the concept and three key strategies of SRI: screening, shareholder advocacy, and community investment. It also traces recent developments in SRI, from the 1960s to 2003. The note gives students an understanding of the rapid growth and performance of socially and environmentally screened investment funds.

- Statman, Meir. (2007) "Socially Responsible Investors and Their Advisors". Santa Clara University - Department of Finance. Available at SSRN: http://ssrn.com/abstract=997085 Accessed: Nov. 14, 2008.

This article presents four financial advisors who advise socially responsible investors. They tell about the life experiences that have drawn them to socially responsible investing and offer lessons about serving socially responsible clients. Socially responsible investors are not only screening their investment choices, but some are also actively involved in changing the behavior of the firms in which they do invest. "We try to find good companies that we can help improve. Clients might be happy to hold a company that's great on human rights but has a lot of work to do on its environmental record as long as they know we're working with the company to improve its record. So our activism complements our investment process".

- Dupre, Denis and Girerd-Potin, Isabelle. (2004) "The Philosophical, Ethical and Economic Foundations of Ethical Investment". Available at SSRN: http://ssrn.com/abstract=497223. Accessed: Nov. 13, 08. 


\section{Macrothink

This paper is theoretical in nature, and offers a good overview of the conceptual underpinnings of ethical investment within a historical context, addressing the traditional Marxist-Capitalism debate in relation to ethical investing. It also relates John Rawls' theory of justice, and Amarty Sen's capabilities and entitlements theory to a discussion on investment decisions. The author makes bold statements about the transformed role of the nation state, alluding to the hollowing out of the state. This certainly invites empirical research to test this statement. Although it offers an interesting argument for the future of SRI initiatives, it makes for good background reading rather than a seminal piece shaping the future of SRI from a policy perspective.

\section{Research Methodology}

The study primarily focuses on those companies that are ranked green by the Newsweek. The suitable approach for the study falls under the category of Exploratory/Descriptive study. The study is categorized under Exploratory study because there is not much research done on this topic and review of literature related to the study is not available. It can be classified under Descriptive study because certain analysis has been done and conclusion has been drawn from them.

The population for the study includes all the companies listed in the US Stock Exchanges. The Sample of 500 companies is considered for the study. These companies are ranked as "green companies" by the Newsweek during the year 2009. The sampling technique followed can be categorized into Non-Probability - Purposive Sampling because the information is obtained from a specific person/organization. The study consists of only secondary data. No primary data were collected for this study. The data was collected from Newsweek's website and the Daily adjusted closing share price of the sample was collected from the Yahoo website. (Yahoo Finance)

The following tools were used for analysis

$$
\text { Return }=\quad \text { Ending price-Beginning price }
$$




\section{ANALYSIS AND INTERTRETATION}

Graph No 1: Average Returns (In \%) for the Top

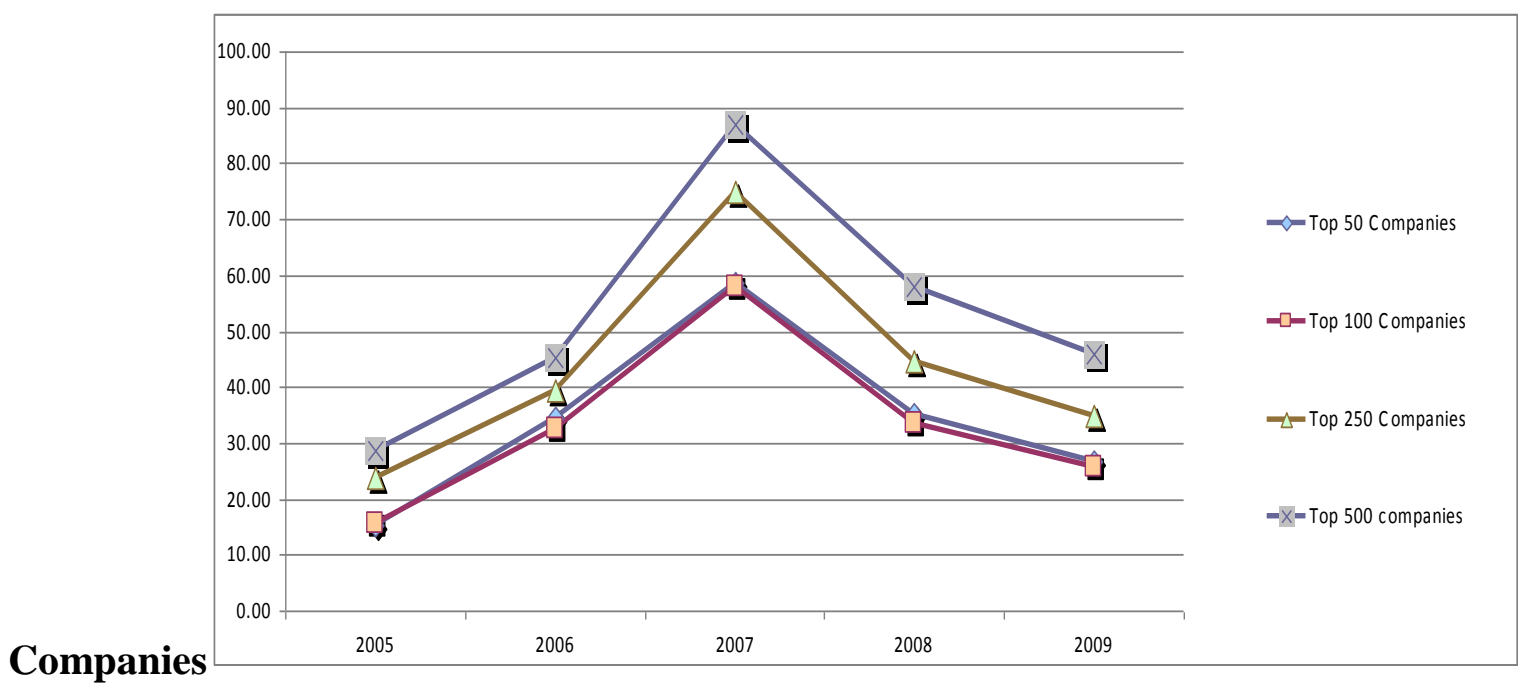

Companies Graph No 1a: Average Returns (In \%) for the Top Companies

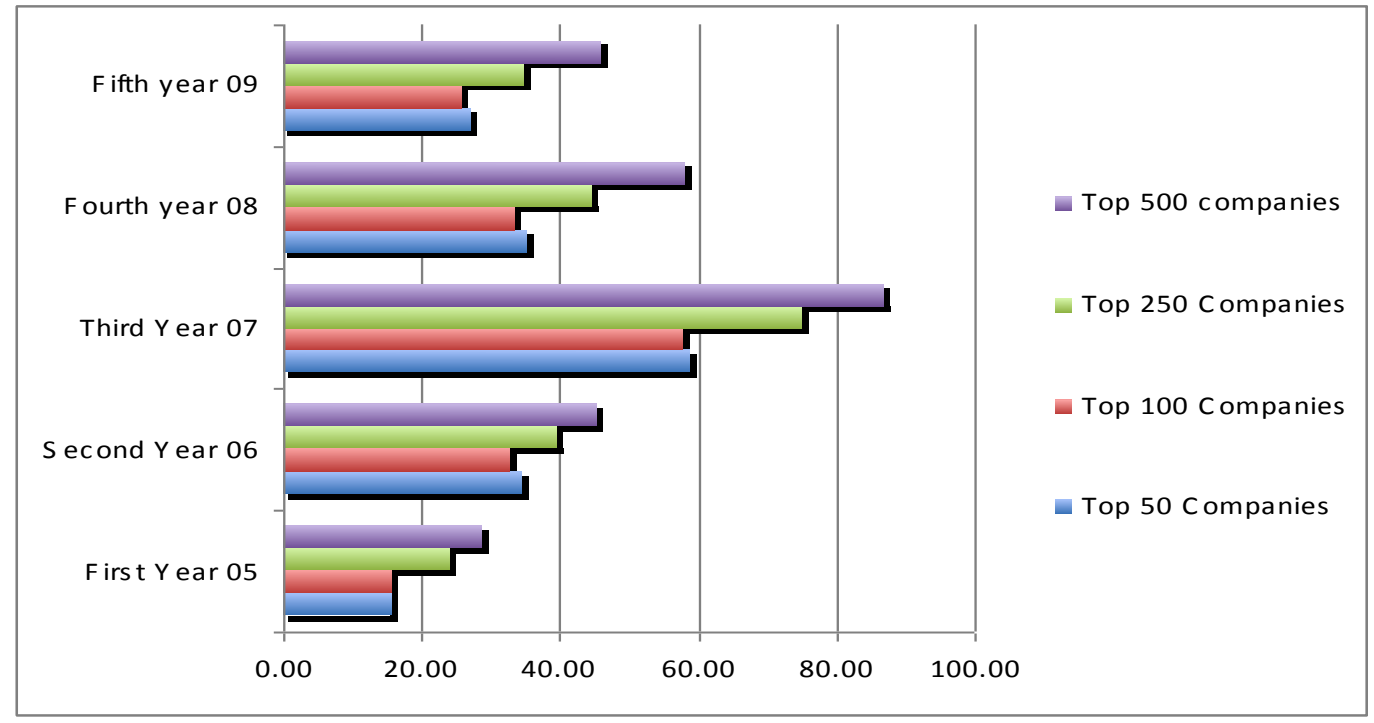

Graph No 2: Average Returns (In \%) for the Indices 


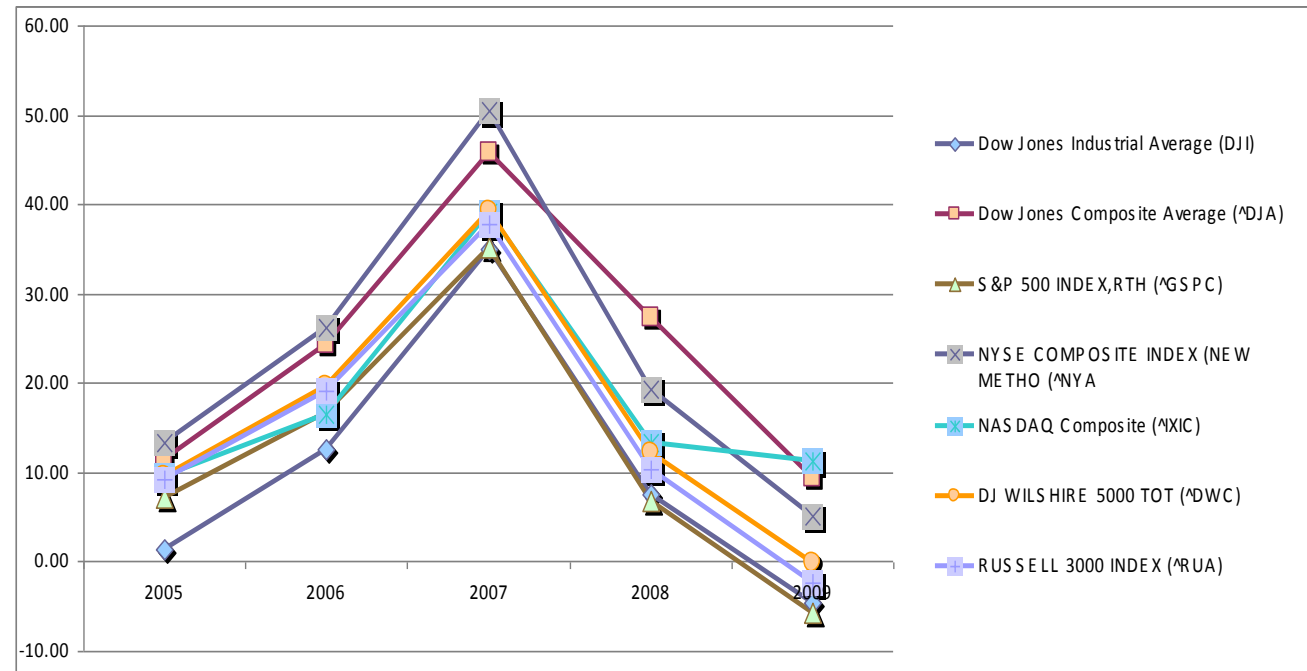

Graph No 2a: Average Returns (In \%) for the Indices

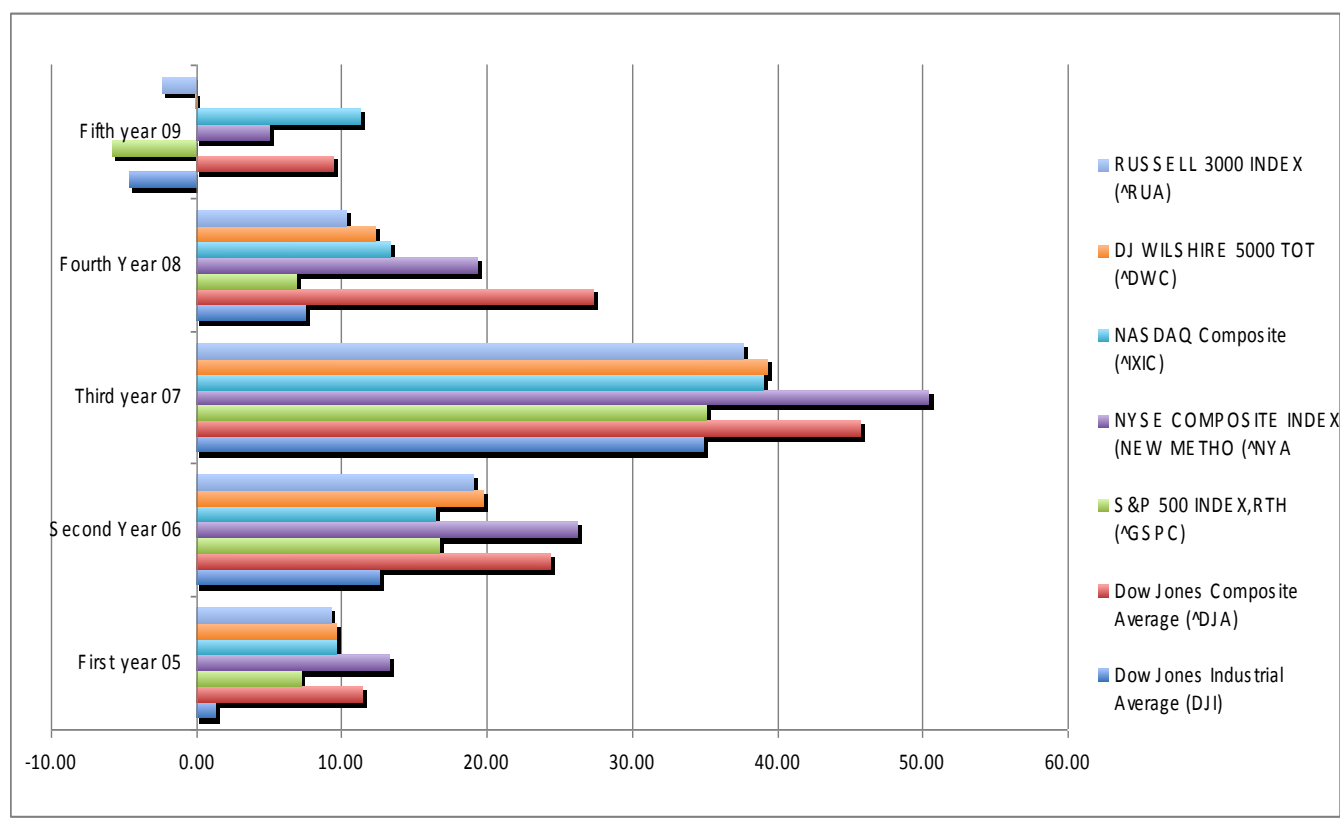

Table No 1: Comparison of the Dow Jones Composite Average (DJA) against Top Companies

\begin{tabular}{|c|c|c|c|c|c|}
\hline Dow Jones Composite Average (DJA) & 11.45 & 24.41 & 45.75 & 27.33 & 9.46 \\
\hline Top 50 Companies & 15.39 & 34.57 & 58.71 & 35.08 & 26.86 \\
\hline Top 100 Companies & 15.70 & 32.69 & 57.83 & 33.53 & 25.80 \\
\hline Top 250 Companies & 23.84 & 39.48 & 74.94 & 44.53 & 34.95 \\
\hline Top 500 companies & 28.82 & 45.31 & 86.92 & 58.07 & 45.97 \\
\hline
\end{tabular}

Table No 1a: The Performance of the Dow Jones Composite Average (DJA) against Top Companies 


\begin{tabular}{|c|c|c|c|c|c|}
\hline Top 50 Companies & 3.94336797 & 10.1610607 & 12.9568457 & 7.7558968 & 17.39986 \\
\hline Top 100 Companies & 4.25393684 & 8.2760154 & 12.0715326 & 6.2034602 & 16.3349 \\
\hline Top 250 Companies & 12.3946955 & 15.0632682 & 29.1864662 & 17.201696 & 25.48143 \\
\hline Top 500 companies & 17.3773546 & 20.8989512 & 41.1627869 & 30.747094 & 36.51056 \\
\hline
\end{tabular}

The above table shows the performance of the top companies against the Dow Jones Composite Average. The performance table depicts the $\%$ by which the top companies have outperformed the Index.

Table No 2: Comparison of the S\&P 500 Index against Top Companies

\begin{tabular}{|l|c|c|c|c|c|}
\hline S\&P 500 INDEX & 7.16 & 16.71 & 35.11 & 6.89 & -5.72 \\
\hline Top 50 Companies & 15.39 & 34.57 & 58.71 & 35.08 & 26.86 \\
\hline Top 100 Companies & 15.70 & 32.69 & 57.83 & 33.53 & 25.80 \\
\hline Top 250 Companies & 23.84 & 39.48 & 74.94 & 44.53 & 34.95 \\
\hline Top 500 companies & 28.82 & 45.31 & 86.92 & 58.07 & 45.97 \\
\hline
\end{tabular}

Table No 2a: Performance of the S\&P 500 Index against Top Companies

\begin{tabular}{|c|c|c|c|c|c|}
\hline Top 50 Companies & 8.227227 & 17.86149 & 23.60485 & 28.19527 & 32.58783 \\
\hline $\begin{array}{c}\text { Top 100 } \\
\text { Companies }\end{array}$ & 8.537795 & 15.97645 & 22.71954 & 26.64283 & 31.52287 \\
\hline $\begin{array}{c}\text { Top 250 } \\
\text { Companies }\end{array}$ & 16.67855 & 22.7637 & 39.83447 & 37.64107 & 40.66939 \\
\hline Top 500 companies & 21.66121 & 28.59939 & 51.81079 & 51.18647 & 51.69852 \\
\hline
\end{tabular}

The above table shows the performance of the top companies against the S \& P 500 Index. The performance table depicts the $\%$ by which the top companies have outperformed the Index.

Table No 3: Performance of the NYSE Composite Index (NYA) against Top Companies

\begin{tabular}{|c|c|c|c|c|c|}
\hline Top 50 Companies & 2.097262 & 8.340657 & 8.22825 & 15.70554 & 21.80801 \\
\hline Top 100 Companies & 2.407831 & 6.455611 & 7.342937 & 14.1531 & 20.74305 \\
\hline Top 250 Companies & 10.54859 & 13.24286 & 24.45787 & 25.15134 & 29.88958 \\
\hline Top 500 companies & 15.53125 & 19.07855 & 36.43419 & 38.69674 & 40.91871 \\
\hline
\end{tabular}

The above table shows the performance of the top companies against the NYSE Composite Index. The performance table depicts the $\%$ by which the top companies have outperformed the Index.

Table No 4: Comparison of the NASDAQ Composite (IXIC) against Top Companies

\begin{tabular}{|c|c|c|c|c|c|}
\hline NASDAQ Composite (IXIC) & 9.65 & 16.48 & 39.04 & 13.42 & 11.29 \\
\hline Top 50 Companies & 15.39 & 34.57 & 58.71 & 35.08 & 26.86 \\
\hline Top 100 Companies & 15.70 & 32.69 & 57.83 & 33.53 & 25.80 \\
\hline Top 250 Companies & 23.84 & 39.48 & 74.94 & 44.53 & 34.95 \\
\hline Top 500 companies & 28.82 & 45.31 & 86.92 & 58.07 & 45.97 \\
\hline
\end{tabular}


Table No 4a: Performance of the NASDAQ Composite (IXIC) against Top Companies

\begin{tabular}{|c|c|c|c|c|c|}
\hline Top 50 Companies & 5.737514 & 18.09572 & 19.67008 & 21.66477 & 15.57607 \\
\hline Top 100 Companies & 6.048083 & 16.21068 & 18.78477 & 20.11233 & 14.51112 \\
\hline Top 250 Companies & 14.18884 & 22.99793 & 35.8997 & 31.11057 & 23.65764 \\
\hline Top 500 companies & 19.1715 & 28.83361 & 47.87602 & 44.65597 & 34.68677 \\
\hline
\end{tabular}

The above table shows the performance of the top companies against the NASDAQ Composite. The performance table depicts the $\%$ by which the top companies have outperformed the Index.

Table No 5: Comparison of the DJ WILSHIRE 5000 TOT (DWC) against Top Companies

\begin{tabular}{|c|c|c|c|c|c|}
\hline DJ WILSHIRE 5000 TOT (DWC) & 9.64 & 19.76 & 39.32 & 12.28 & -0.09 \\
\hline Top 50 Companies & 15.39 & 34.57 & 58.71 & 35.08 & 26.86 \\
\hline Top 100 Companies & 15.70 & 32.69 & 57.83 & 33.53 & 25.80 \\
\hline Top 250 Companies & 23.84 & 39.48 & 74.94 & 44.53 & 34.95 \\
\hline Top 500 companies & 28.82 & 45.31 & 86.92 & 58.07 & 45.97 \\
\hline
\end{tabular}

Table No 5a: Performance of the DJ WILSHIRE 5000 TOT (DWC) against Top Companies

\begin{tabular}{|c|c|c|c|c|c|}
\hline Top 50 Companies & 5.748079683 & 14.8119419 & 19.39531 & 22.80318 & 26.95566 \\
\hline Top 100 Companies & 6.058648561 & 12.9268966 & 18.51 & 21.25074 & 25.8907 \\
\hline Top 250 Companies & 14.1994072 & 19.7141494 & 35.62493 & 32.24898 & 35.03723 \\
\hline Top 500 companies & 19.18206632 & 25.5498323 & 47.60125 & 45.79437 & 46.06636 \\
\hline
\end{tabular}

The above table shows the performance of the top companies against the DJ WILSHIRE

5000 TOT. The performance table depicts the $\%$ by which the top companies have outperformed the Index.

Table No 6: Comparison of the RUSSELL 3000 INDEX (RUA) against Top Companies

\begin{tabular}{|c|c|c|c|c|c|}
\hline RUSSELL 3000 INDEX (RUA) & 9.25 & 19.07 & 37.72 & 10.37 & -2.36 \\
\hline Top 50 Companies & 15.39 & 34.57 & 58.71 & 35.08 & 26.86 \\
\hline Top 100 Companies & 15.70 & 32.69 & 57.83 & 33.53 & 25.80 \\
\hline Top 250 Companies & 23.84 & 39.48 & 74.94 & 44.53 & 34.95 \\
\hline Top 500 companies & 28.82 & 45.31 & 86.92 & 58.07 & 45.97 \\
\hline
\end{tabular}

Table No 6a: Performance of the RUSSELL 3000 INDEX (RUA) against Top Companies

\begin{tabular}{|c|c|c|c|c|c|}
\hline Top 50 Companies & 6.139332 & 15.50503 & 20.98734 & 24.71535 & 29.22525 \\
\hline Top 100 Companies & 6.449901 & 13.61998 & 20.10203 & 23.16292 & 28.16029 \\
\hline Top 250 Companies & 14.59066 & 20.40723 & 37.21697 & 34.16115 & 37.30681 \\
\hline Top 500 companies & 19.57332 & 26.24292 & 49.19329 & 47.70655 & 48.33594 \\
\hline
\end{tabular}


The above table shows the performance of the top companies against the Russell 3000 Index. The performance table depicts the $\%$ by which the top companies have outperformed the Index.

Graph No 3: Top 50

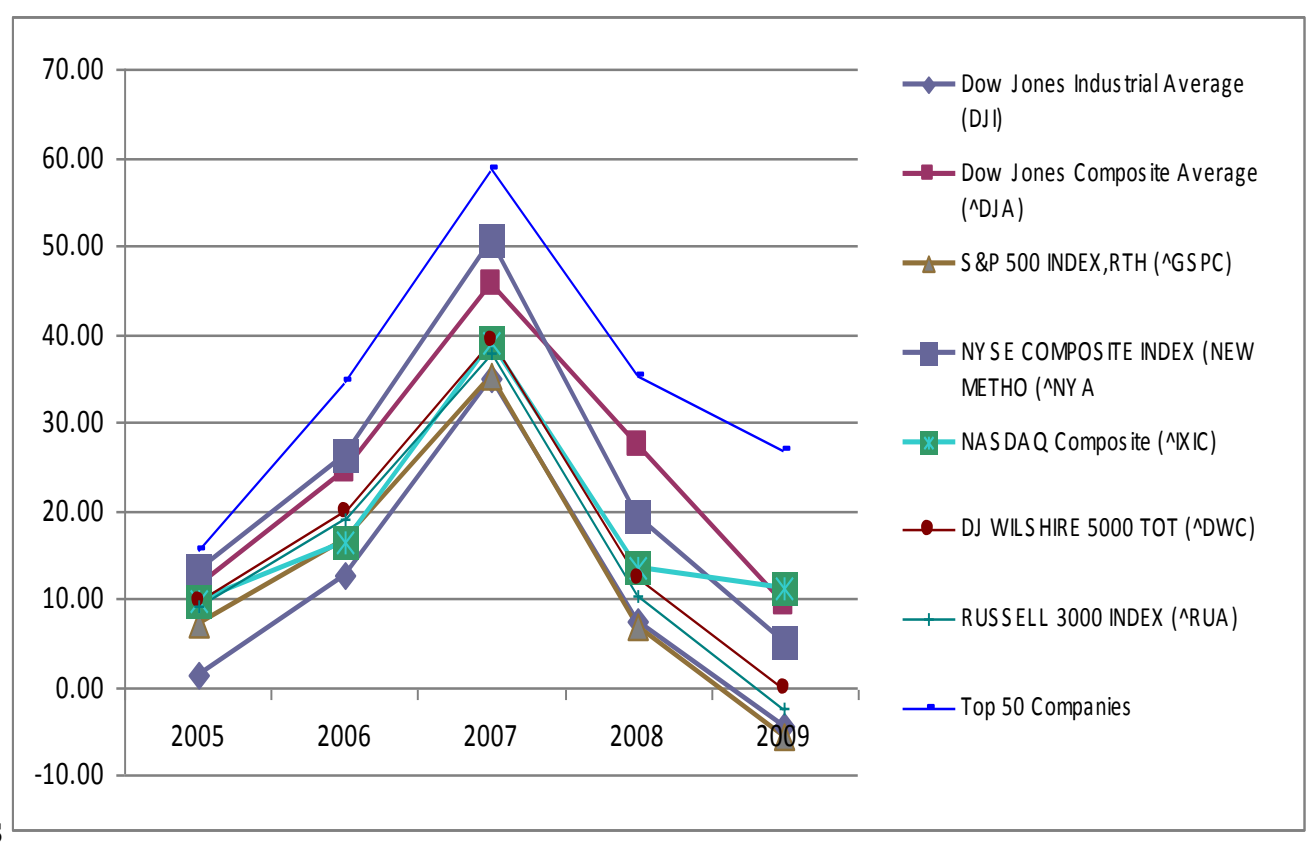

\section{Companies}

It can be inferred from the above graph that the top 50 companies has outperformed all the indices for the period ranging 2005-2009.

Table No 7: Comparison of the Top 50 Companies against the Indices

\begin{tabular}{|l|l|l|l|l|l|}
\hline Top 50 Companies & 15.39 & 34.57 & 58.71 & 35.08 & 26.86 \\
\hline $\begin{array}{l}\text { Dow Jones Industrial Average } \\
\text { (DJI) }\end{array}$ & 1.30 & 12.58 & 34.90 & 7.52 & -4.55 \\
\hline $\begin{array}{l}\text { Dow Jones Composite Average } \\
\text { (DJA) }\end{array}$ & 11.45 & 24.41 & 45.75 & 27.33 & 9.46 \\
\hline S\&P 500 INDEX,RTH (GSPC) & 7.16 & 16.71 & 35.11 & 6.89 & -5.72 \\
\hline $\begin{array}{l}\text { NYSE COMPOSITE INDEX } \\
\text { (NEW METHO (NYA) }\end{array}$ & 13.29 & 26.23 & 50.48 & 19.38 & 5.06 \\
\hline NASDAQ Composite (IXIC) & 9.65 & 16.48 & 39.04 & 13.42 & 11.29 \\
\hline $\begin{array}{l}\text { DJ WILSHIRE 5000 TOT } \\
\text { (DWC) }\end{array}$ & 9.64 & 19.76 & 39.32 & 12.28 & -0.09 \\
\hline RUSSELL 3000 INDEX (RUA) & 9.25 & 19.07 & 37.72 & 10.37 & -2.36 \\
\hline
\end{tabular}

Table No 8: Comparison of the Top 100 Companies against the Indices

\begin{tabular}{|l|l|l|l|l|l|}
\hline Top 100 Companies & $\begin{array}{l}15.7 \\
0\end{array}$ & $\begin{array}{l}32.6 \\
9\end{array}$ & $\begin{array}{l}57.8 \\
3\end{array}$ & $\begin{array}{l}33.5 \\
3\end{array}$ & $\begin{array}{l}25.8 \\
0\end{array}$ \\
\hline Dow Jones Industrial Average (DJI) & 1.30 & $\begin{array}{l}12.5 \\
8\end{array}$ & $\begin{array}{l}34.9 \\
0\end{array}$ & 7.52 & -4.55 \\
\hline
\end{tabular}




\begin{tabular}{|l|l|l|l|l|l|}
\hline $\begin{array}{l}\text { Dow Jones Composite Average } \\
\text { (DJA) }\end{array}$ & $\begin{array}{l}11.4 \\
5\end{array}$ & $\begin{array}{l}24.4 \\
1\end{array}$ & $\begin{array}{l}45.7 \\
5\end{array}$ & $\begin{array}{l}27.3 \\
3\end{array}$ & 9.46 \\
\hline S\&P 500 INDEX,RTH (GSPC) & 7.16 & $\begin{array}{l}16.7 \\
1\end{array}$ & $\begin{array}{l}35.1 \\
1\end{array}$ & 6.89 & -5.72 \\
\hline $\begin{array}{l}\text { NYSE COMPOSITE INDEX (NEW } \\
\text { METHO (NYA) }\end{array}$ & $\begin{array}{l}13.2 \\
9\end{array}$ & $\begin{array}{l}26.2 \\
3\end{array}$ & $\begin{array}{l}50.4 \\
8\end{array}$ & $\begin{array}{l}19.3 \\
8\end{array}$ & 5.06 \\
\hline NASDAQ Composite (IXIC) & 9.65 & $\begin{array}{l}16.4 \\
8\end{array}$ & $\begin{array}{l}39.0 \\
4\end{array}$ & $\begin{array}{l}13.4 \\
2\end{array}$ & $\begin{array}{l}11.2 \\
9\end{array}$ \\
\hline DJ WILSHIRE 5000 TOT (DWC) & 9.64 & $\begin{array}{l}19.7 \\
6\end{array}$ & $\begin{array}{l}39.3 \\
2\end{array}$ & $\begin{array}{l}12.2 \\
8\end{array}$ & -0.09 \\
\hline RUSSELL 3000 INDEX (RUA) & 9.25 & $\begin{array}{l}19.0 \\
7\end{array}$ & $\begin{array}{l}37.7 \\
2\end{array}$ & $\begin{array}{l}10.3 \\
7\end{array}$ & -2.36 \\
\hline
\end{tabular}

Table No 9: Comparison of the Top 250 Companies against the Indices

\begin{tabular}{|l|l|l|l|l|l|}
\hline Top 250 Companies & 23.84 & 39.48 & 74.94 & 44.53 & 34.95 \\
\hline Dow Jones Industrial Average (DJI) & 1.30 & 12.58 & 34.90 & 7.52 & -4.55 \\
\hline Dow Jones Composite Average (DJA) & 11.45 & 24.41 & 45.75 & 27.33 & 9.46 \\
\hline S\&P 500 INDEX,RTH (GSPC) & 7.16 & 16.71 & 35.11 & 6.89 & -5.72 \\
\hline $\begin{array}{l}\text { NYSE COMPOSITE INDEX (NEW } \\
\text { METHO (NYA) }\end{array}$ & 13.29 & 26.23 & 50.48 & 19.38 & 5.06 \\
\hline NASDAQ Composite (IXIC) & 9.65 & 16.48 & 39.04 & 13.42 & 11.29 \\
\hline DJ WILSHIRE 5000 TOT (DWC) & 9.64 & 19.76 & 39.32 & 12.28 & -0.09 \\
\hline RUSSELL 3000 INDEX (RUA) & 9.25 & 19.07 & 37.72 & 10.37 & -2.36 \\
\hline
\end{tabular}

Table No 10: Comparison of the Top 500 Companies against the Indices

\begin{tabular}{|c|c|c|c|c|c|}
\hline Top 500 companies & $\begin{array}{l}28.8 \\
2\end{array}$ & $\begin{array}{l}45.3 \\
1\end{array}$ & $\begin{array}{l}86.9 \\
2\end{array}$ & $\begin{array}{l}58.0 \\
7\end{array}$ & 45.97 \\
\hline Dow Jones Industrial Average (DJI) & 1.30 & $\begin{array}{l}12.5 \\
8\end{array}$ & $\begin{array}{l}34.9 \\
0\end{array}$ & 7.52 & -4.55 \\
\hline $\begin{array}{l}\text { Dow Jones Composite Average } \\
\text { (DJA) }\end{array}$ & $\begin{array}{l}11.4 \\
5\end{array}$ & $\begin{array}{l}24.4 \\
1\end{array}$ & $\begin{array}{l}45.7 \\
5\end{array}$ & $\begin{array}{l}27.3 \\
3\end{array}$ & 9.46 \\
\hline S\&P 500 INDEX,RTH (GSPC) & 7.16 & $\begin{array}{l}16.7 \\
1\end{array}$ & $\begin{array}{l}35.1 \\
1\end{array}$ & 6.89 & -5.72 \\
\hline $\begin{array}{l}\text { NYSE COMPOSITE INDEX } \\
\text { (NEW METHO (NYA) }\end{array}$ & $\begin{array}{l}13.2 \\
9\end{array}$ & $\begin{array}{l}26.2 \\
3\end{array}$ & $\begin{array}{l}50.4 \\
8 \\
\end{array}$ & $\begin{array}{l}19.3 \\
8\end{array}$ & 5.06 \\
\hline NASDAQ Composite (IXIC) & 9.65 & $\begin{array}{l}16.4 \\
8\end{array}$ & $\begin{array}{l}39.0 \\
4\end{array}$ & $\begin{array}{l}13.4 \\
2\end{array}$ & 11.29 \\
\hline DJ WILSHIRE 5000 TOT (DWC) & 9.64 & $\begin{array}{l}19.7 \\
6 \\
\end{array}$ & $\begin{array}{l}39.3 \\
2\end{array}$ & $\begin{array}{l}12.2 \\
8 \\
\end{array}$ & -0.09 \\
\hline RUSSELL 3000 INDEX (RUA) & 9.25 & $\begin{array}{l}19.0 \\
7 \\
\end{array}$ & $\begin{array}{l}37.7 \\
2\end{array}$ & $\begin{array}{l}10.3 \\
7\end{array}$ & -2.36 \\
\hline
\end{tabular}


Table No 11: Comparison of the Top 1-100 Companies against the Indices

\begin{tabular}{|c|c|c|c|c|c|}
\hline Top $1-100$ & $\begin{array}{l}15.7 \\
0\end{array}$ & $\begin{array}{l}32.6 \\
9\end{array}$ & $\begin{array}{l}57.8 \\
3\end{array}$ & $\begin{array}{l}33.5 \\
3\end{array}$ & $\begin{array}{l}25.8 \\
0\end{array}$ \\
\hline $\begin{array}{l}\text { Dow Jones Industrial Average } \\
\text { (DJI) }\end{array}$ & 1.30 & $\begin{array}{l}12.5 \\
8\end{array}$ & $\begin{array}{l}34.9 \\
0\end{array}$ & 7.52 & -4.55 \\
\hline $\begin{array}{l}\text { Dow Jones Composite Average } \\
\text { (DJA) }\end{array}$ & $\begin{array}{l}11.4 \\
5\end{array}$ & $\begin{array}{l}24.4 \\
1\end{array}$ & $\begin{array}{l}45.7 \\
5\end{array}$ & $\begin{array}{l}27.3 \\
3\end{array}$ & 9.46 \\
\hline S\&P 500 INDEX,RTH (GSPC) & 7.16 & $\begin{array}{l}16.7 \\
1\end{array}$ & $\begin{array}{l}35.1 \\
1\end{array}$ & 6.89 & -5.72 \\
\hline $\begin{array}{l}\text { NYSE COMPOSITE INDEX } \\
\text { (NEW METHO (NYA) }\end{array}$ & $\begin{array}{l}13.2 \\
9\end{array}$ & $\begin{array}{l}26.2 \\
3\end{array}$ & $\begin{array}{l}50.4 \\
8\end{array}$ & $\begin{array}{l}19.3 \\
8\end{array}$ & 5.06 \\
\hline NASDAQ Composite (IXIC) & 9.65 & $\begin{array}{l}16.4 \\
8\end{array}$ & $\begin{array}{l}39.0 \\
4\end{array}$ & $\begin{array}{l}13.4 \\
2\end{array}$ & $\begin{array}{l}11.2 \\
9\end{array}$ \\
\hline DJ WILSHIRE 5000 TOT (DWC) & 9.64 & $\begin{array}{l}19.7 \\
6\end{array}$ & $\begin{array}{l}39.3 \\
2\end{array}$ & $\begin{array}{l}12.2 \\
8\end{array}$ & -0.09 \\
\hline RUSSELL 3000 INDEX (RUA) & 9.25 & $\begin{array}{l}19.0 \\
7\end{array}$ & $\begin{array}{l}37.7 \\
2\end{array}$ & $\begin{array}{l}10.3 \\
7\end{array}$ & -2.36 \\
\hline
\end{tabular}

Table No 12: Comparison of the Top 101-200 Companies against the Indices

\begin{tabular}{|c|c|c|c|c|c|}
\hline Top $101-200$ & $\begin{array}{l}32.4 \\
4\end{array}$ & $\begin{array}{l}45.8 \\
0\end{array}$ & $\begin{array}{l}91.5 \\
1\end{array}$ & $\begin{array}{l}54.8 \\
8\end{array}$ & $\begin{array}{l}44.9 \\
2\end{array}$ \\
\hline Dow Jones Industrial Average (DJI) & 1.30 & $\begin{array}{l}12.5 \\
8\end{array}$ & $\begin{array}{l}34.9 \\
0\end{array}$ & 7.52 & -4.55 \\
\hline Dow Jones Composite Average (DJA) & $\begin{array}{l}11.4 \\
5\end{array}$ & $\begin{array}{l}24.4 \\
1\end{array}$ & $\begin{array}{l}45.7 \\
5\end{array}$ & $\begin{array}{l}27.3 \\
3\end{array}$ & 9.46 \\
\hline S\&P 500 INDEX,RTH (GSPC) & 7.16 & $\begin{array}{l}16.7 \\
1\end{array}$ & $\begin{array}{l}35.1 \\
1\end{array}$ & 6.89 & -5.72 \\
\hline $\begin{array}{l}\text { NYSE COMPOSITE INDEX (NEW } \\
\text { METHO (NYA) }\end{array}$ & $\begin{array}{l}13.2 \\
9\end{array}$ & $\begin{array}{l}26.2 \\
3\end{array}$ & $\begin{array}{l}50.4 \\
8\end{array}$ & $\begin{array}{l}19.3 \\
8\end{array}$ & 5.06 \\
\hline NASDAQ Composite (IXIC) & 9.65 & $\begin{array}{l}16.4 \\
8\end{array}$ & $\begin{array}{l}39.0 \\
4\end{array}$ & $\begin{array}{l}13.4 \\
2\end{array}$ & $\begin{array}{l}11.2 \\
9\end{array}$ \\
\hline DJ WILSHIRE 5000 TOT (DWC) & 9.64 & $\begin{array}{l}19.7 \\
6\end{array}$ & $\begin{array}{l}39.3 \\
2\end{array}$ & $\begin{array}{l}12.2 \\
8\end{array}$ & -0.09 \\
\hline RUSSELL 3000 INDEX (RUA) & 9.25 & $\begin{array}{l}19.0 \\
7\end{array}$ & $\begin{array}{l}37.7 \\
2\end{array}$ & $\begin{array}{l}10.3 \\
7\end{array}$ & -2.36 \\
\hline
\end{tabular}

Table No 13: Comparison of the Top 201-300 Companies against the Indices

\begin{tabular}{|l|l|l|l|l|l|}
\hline Top 201 - 300 & $\begin{array}{l}29.9 \\
6\end{array}$ & $\begin{array}{l}45.7 \\
2\end{array}$ & $\begin{array}{l}88.6 \\
4\end{array}$ & $\begin{array}{l}61.0 \\
3\end{array}$ & $\begin{array}{l}46.9 \\
6\end{array}$ \\
\hline $\begin{array}{l}\text { Dow Jones Industrial Average } \\
\text { (DJ) }\end{array}$ & 1.30 & $\begin{array}{l}12.5 \\
8\end{array}$ & $\begin{array}{l}34.9 \\
0\end{array}$ & 7.52 & -4.55 \\
\hline $\begin{array}{l}\text { Dow Jones Composite Average } \\
\text { (DJA) }\end{array}$ & $\begin{array}{l}11.4 \\
5\end{array}$ & $\begin{array}{l}24.4 \\
1\end{array}$ & $\begin{array}{l}45.7 \\
5\end{array}$ & $\begin{array}{l}27.3 \\
3\end{array}$ & 9.46 \\
\hline
\end{tabular}




\begin{tabular}{|l|l|l|l|l|l|}
\hline S\&P 500 INDEX,RTH (GSPC) & 7.16 & $\begin{array}{l}16.7 \\
1\end{array}$ & $\begin{array}{l}35.1 \\
1\end{array}$ & 6.89 & -5.72 \\
\hline NYSE COMPOSITE INDEX & $\begin{array}{l}13.2 \\
9\end{array}$ & $\begin{array}{l}26.2 \\
3\end{array}$ & $\begin{array}{l}50.4 \\
8\end{array}$ & $\begin{array}{l}19.3 \\
8\end{array}$ & 5.06 \\
\hline NEW METHO (NYA) & 9.65 & $\begin{array}{l}16.4 \\
8\end{array}$ & $\begin{array}{l}39.0 \\
4\end{array}$ & $\begin{array}{l}13.4 \\
2\end{array}$ & $\begin{array}{l}11.2 \\
9\end{array}$ \\
\hline NASDAQ Composite (IXIC) & & $\begin{array}{l}19.7 \\
6\end{array}$ & $\begin{array}{l}39.3 \\
2\end{array}$ & $\begin{array}{l}12.2 \\
8\end{array}$ & -0.09 \\
\hline DJ WILSHIRE 5000 TOT (DWC) & 9.64 & & $\begin{array}{l}67.7 \\
10.3\end{array}$ & -2.36 \\
\hline RUSSELL 3000 INDEX (RUA) & 9.25 & $\begin{array}{l}19 \\
7\end{array}$ & \\
\hline
\end{tabular}

Table No 14: Comparison of the Top 301-400 Companies against the Indices

\begin{tabular}{|l|l|l|l|l|l|}
\hline Top 301 - 400 & $\begin{array}{l}28.0 \\
8\end{array}$ & $\begin{array}{l}49.1 \\
4\end{array}$ & $\begin{array}{l}97.4 \\
0\end{array}$ & $\begin{array}{l}57.9 \\
7\end{array}$ & 44.35 \\
\hline Dow Jones Industrial Average (DJI) & 1.30 & $\begin{array}{l}12.5 \\
8\end{array}$ & $\begin{array}{l}34.9 \\
0\end{array}$ & 7.52 & -4.55 \\
\hline $\begin{array}{l}\text { Dow Jones Composite Average } \\
\text { (DJA) }\end{array}$ & $\begin{array}{l}11.4 \\
5\end{array}$ & $\begin{array}{l}24.4 \\
1\end{array}$ & $\begin{array}{l}45.7 \\
5\end{array}$ & $\begin{array}{l}27.3 \\
3\end{array}$ & 9.46 \\
\hline S\&P 500 INDEX,RTH (GSPC) & 7.16 & $\begin{array}{l}16.7 \\
1\end{array}$ & $\begin{array}{l}35.1 \\
1\end{array}$ & 6.89 & -5.72 \\
\hline NYSE COMPOSITE INDEX (NEW & $\begin{array}{l}13.2 \\
\text { METHO (NYA) }\end{array}$ & $\begin{array}{l}26.2 \\
3\end{array}$ & $\begin{array}{l}50.4 \\
8\end{array}$ & $\begin{array}{l}19.3 \\
8\end{array}$ & 5.06 \\
\hline NASDAQ Composite (IXIC) & 9.65 & $\begin{array}{l}16.4 \\
8\end{array}$ & $\begin{array}{l}39.0 \\
4\end{array}$ & $\begin{array}{l}13.4 \\
2\end{array}$ & 11.29 \\
\hline DJ WILSHIRE 5000 TOT (DWC) & 9.64 & $\begin{array}{l}19.7 \\
6\end{array}$ & $\begin{array}{l}39.3 \\
2\end{array}$ & $\begin{array}{l}12.2 \\
8\end{array}$ & -0.09 \\
\hline RUSSELL 3000 INDEX (RUA) & 9.25 & $\begin{array}{l}19.0 \\
7\end{array}$ & $\begin{array}{l}37.7 \\
2\end{array}$ & $\begin{array}{l}10.3 \\
7\end{array}$ & -2.36 \\
\hline
\end{tabular}

Table No 15: Comparison of the Top 401-500 Companies against the Indices

\begin{tabular}{|l|l|l|l|l|l|}
\hline Top 401 - 500 & $\begin{array}{l}38.9 \\
2\end{array}$ & $\begin{array}{l}53.6 \\
4\end{array}$ & 100.12 & $\begin{array}{l}84.4 \\
4\end{array}$ & $\begin{array}{l}68.2 \\
7\end{array}$ \\
\hline Dow Jones Industrial Average (DJI) & 1.30 & $\begin{array}{l}12.5 \\
8\end{array}$ & 34.90 & 7.52 & -4.55 \\
\hline $\begin{array}{l}\text { Dow Jones Composite Average } \\
\text { (DJA) }\end{array}$ & $\begin{array}{l}11.4 \\
5\end{array}$ & $\begin{array}{l}24.4 \\
1\end{array}$ & 45.75 & $\begin{array}{l}27.3 \\
3\end{array}$ & 9.46 \\
\hline S\&P 500 INDEX,RTH (GSPC) & 7.16 & $\begin{array}{l}16.7 \\
1\end{array}$ & 35.11 & 6.89 & -5.72 \\
\hline $\begin{array}{l}\text { NYSE COMPOSITE INDEX } \\
\text { (NEW METHO (NYA) }\end{array}$ & $\begin{array}{l}13.2 \\
9\end{array}$ & $\begin{array}{l}26.2 \\
3\end{array}$ & 50.48 & $\begin{array}{l}19.3 \\
8\end{array}$ & 5.06 \\
\hline NASDAQ Composite (IXIC) & 9.65 & $\begin{array}{l}16.4 \\
8\end{array}$ & 39.04 & $\begin{array}{l}13.4 \\
2\end{array}$ & $\begin{array}{l}11.2 \\
9\end{array}$ \\
\hline DJ WILSHIRE 5000 TOT (DWC) & 9.64 & 19.7 & 39.32 & 12.2 & -0.09 \\
\hline
\end{tabular}




\section{FINDINGS}

- The pattern of returns from the green rated companies is similar to the market returns except the fact that they outperform the indices.

The Top 50,100,250 and 500 companies have outperformed the various indices like_Dow Jones Industrials (DJI), Dow Jones Composite (DJA), S\&P 500 (GSPC), NYSE Composite (NYA), NASDAQ Composite (IXIC), Dow Jones Wilshire (DWC), Russell 3000 (RUA). It is also found that the cluster of 1-100, 101-200,201-300,301-400 and 401-500 has also outperformed the broad market return and gives better average returns than any indices selected for comparison, which indicates that a group of green rated companies perform better than the indices.

- It was found that the average return of top companies 401-500 is more than all others top companies (i.e. 1-100, 101-200, 201-300, 301-400) in the list, which tells us that companies ranked the last 100, perform financially better than first 400 .

It can be supported by fact that most of high profit making companies such as Chesapeake Energy, Diamond Offshore Drilling, and Occidental Petroleum are ranked in the last 100.

- As most group of ranked companies perform better than the indices compared in the study, it can be said that the companies present in indices are not able to match the returns that the green rated companies of Newsweek fetches.

- The average returns of all companies (i.e. 1-100, 101-200, 201-300, 301-400, 401-500) starts decreasing in fourth and fifth year, 2008 and 2009 respectively due to global "slowdown", which affected all the companies listed in the stock market.

\section{Recommendations}

- Investors are demanding green products which have a lesser amount of impact on the environment and are willing to pay extra. Thus there lies a huge potential for companies that manufacture green/ eco-friendly products.

- Multiple Portfolio's can be constructed using portfolio models like Markowitz model, CAPM model, MPT model etc from the top 500 ranked companies.

- Investor who wants to invest in hardcore green companies can invest in the top 100 companies though they do not give higher returns when compared to the other companies in the list.

- Green companies are now gaining greater consumer acceptance and investors can invest their money in green businesses because sustainable practices are profitable in the long term. 


\section{Al Macrothink}

\section{Conclusion}

It is understood from the study that the corporations in the USA have started realising the need for going green. It is evident that the top ranked 500 green companies have outperformed the broad market return. Many companies have understood that environmental issues are a vital part of a company's economic well-being. Multiple Portfolios' can be constructed for the investors who are interested in investing in hardcore green companies.

From the analysis done it can be concluded that a new wave of environmental investors is looking at environmental protection as an opportunity, and they are investing in market sectors that are eco-friendly and are responsible. Investors now have a greater chance of making money by investing in these green companies and the new technologies. Companies seem to be positive and are focusing on sustainability as it reduces cost and also helps to protect the environment. Many citizens throughout the world are demanding environmentally friendly products and it can be concluded from the study that the future of sustainability looks green.

\section{References}

- Pete Engardio, with Kerry Capell in London, John Carey in Washington, and Kenji Hall (2007),Beyond The Green Corporation; Imagine a world in which eco-friendly and socially responsible practices actually help a company's bottom line. It's closer than you think, Business week, Issue 4019.

- Engardo, Pete (2007) "Beyond the Green Corporations." Business Week, issue 4019,

- Martin de Sa'Pinto,( 2008), Green investing proves a winning strategy-study, Reuters ,retrieved on November 13,2008 from http://www.reuters.com/article/2008/11/13/sarasin-idUSLD42379620081113

- The Clean tech Market Authority(2009), The First Trust NASDAQ® Clean Edge ${ }^{\circledR}$ Green Energy Index Fund is based on the NASDAQ ${ }^{\circledR}$ Clean Edge ${ }^{\circledR}$ Green Energy Index (CELS) and is sponsored by First Trust Advisors L.P retrieved on June 30,2009, September 30,2009 and December 31,2009 from http://www.cleanedge.com/

- Rob Watson (2009), The Green Building Market and Impact Report 2009, retrieved on November5 2009 from

\section{http://www.greenbiz.com/}

- Joel Makower, Rob Watson (2009), The State of Green Business 2009: Green Marketing Suffers a Failure to Communicate, Game-Changers, retrieved on December 30,2009, from http://www.greenbizleaders.com/ 


\section{Macrothink

- Green Biz staff (2009), State of Green Business 2009: Green is Growing, But Not Fast Enough, retrieved on September 20,2009, from

http://www.stateofgreenbusiness.com/

- Elisabeth Eaves (2007)Going Green How to travel Green, retrieved on September 17,2004, from

http://www.msnbc.msn.com/id/17950339/

- Green Rankings 2009: Methodology, retrieved on September 15,2009, from http://www.newsweek.com/id/215522

- Newsweek Green Rankings 2009 FAQ, retrieved on 30,December 2009, from http://greenrankings.newsweek.com/

- Zoe Van Schyndel(2007) Go Green With Socially Responsible Investing ,retrieved on September 13,2007, from

http://www.investopedia.com/articles/07/clean_and_green.asp?viewed=1

- Richard Wilson (2009),Socially Responsible Investing:Guide to Socially Responsible Investing, retrieved on October 13,2009 from

http://richard-wilson.blogspot.com/2008/09/socially-responsible-investing.html 